\section{'AC Harrow Gold' Pear}

David M. Hunter ${ }^{1}$

Agriculture and Agri-Food Canada, Southern Crop Protection and Food Research Centre, Vineland Station, ON, LOR 2EO, Canada

Frank Kappel and Harvey A. Quamme

Agriculture and Agri-Food Canada, Pacific Agri-Food Research Centre, Summerland, BC, VOH 1ZO, Canada

W. Gordon Bonn ${ }^{2}$

Agriculture and Agri-Food Canada, Greenhouse and Processing Crops Research Centre, Harrow, ON, NOR 1GO, Canada

Additional index words. Pyrus communis, fire blight, Erwinia amylovora, resistance
'AC Harrow Gold' pear (Pyrus communis L.) is a high-quality, early-season, fresh-market pear. The tree is moderately productive with no evidence of a biennial bearing habit, and has excellent resistance to fire blight [Erwinia amylovora (Burr.) Winslow et al.]. This new cultivar, developed by Agriculture and Agri-Food Canada at Harrow, Ontario, Canada, is recommended by the Ontario Tender Fruit Producers' Marketing Board for trial planting in Ontario. It is being protected under Canadian Plant Breeders Rights legislation (application number 00-2185).

\section{Origin}

'AC Harrow Gold' originated from a cross of 'Harvest Queen' (Quamme and Spearman, 1983) x 'Harrow Delight' (Quamme and Spearman, 1983) made in 1975 by H.A. Quamme at Harrow (Fig. 1). 'AC Harrow Gold' was selected in 1981 by H.A. Quamme and G. Spearman and propagated in 1985 for eration with the Western Ontario Fruit Testing Association (now the Ontario Fruit Testing Association), and placed in regional trials with cooperating growers beginning in 1987 under the designation HW616. 'AC Harrow Gold' was included in regional evaluation orchards planted in Ontario in 1992. It was also included in a 1999 planting of fire blight resistant cultivars and selections for evaluation of commercial processing capabilities. 'AC Harrow Gold' has been tested in Canada, the United States, and in Europe. for publication 9 May 2001. We thank P. Pinsonneault, P.R. Timmins, M.F. Gadsby, and D.B. Jessop for excellent technical assistance. We appreTesting Association and its grower-members in field performance evaluations.

${ }^{1}$ To whom reprint requests should be addressed. Current address: Univ. of Guelph, Dept. of Plant Agriculture, 4890 Victoria Ave. N., P.O. Box 7000, Vineland Station ON Canada. E-mail: dhunter@uoguelph.ca

${ }^{2}$ Present address: BIOBONNEX Inc., 1035 Beals Street, Windsor, ON, N9E 4B7, Canada. second test. Trees were propagated in coop-

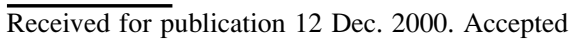
ciate the assistance of the Western Ontario Fruit

\section{Description and Performance:}

\section{Tree characteristics}

Tree habit and productivity. The tree of 'AC Harrow Gold' is medium in size, upright to spreading, annually productive and winter hardy. In 1994 at Harrow, following winter minimum temperatures as low as $-29^{\circ} \mathrm{C}$, a full crop was produced by the original seedling tree, as well as by trees grown on Bartlett seedling rootstock. The original seedling tree has consistently produced good crops with no evidence of biennial bearing. Precocity of 'AC Harrow Gold' trees propagated on Bartlett seedling rootstock appears to be similar to that of 'Bartlett', with bearing initiated $\approx 4$ years after planting. Annual yields in the early years of production have been slightly lower than those of 'Bartlett', except when fire blight infections have reduced 'Bartlett' performance.

Shoot habit. The bark on the sun-exposed side of dormant shoots is light brown with olive (RHS 199A, Royal Horticultural Society, 1966). The diameter of dormant shoots of 'AC Harrow Gold' is similar to that of 'Bartlett' (data not presented). Mean internode length of 'AC Harrow Gold' was similar to 'Bartlett', 'Harrow Delight', and 'Harrow Sweet', but shorter than 'Harvest Queen' and 'Bosc' (Table 1).
Table 1. Mean internode length $(\mathrm{cm} \pm \mathrm{SE})$ as determined on five successive internodes from the midportion of 1-year-old shoots ${ }^{\mathrm{z}}$.

\begin{tabular}{lcc}
\hline Cultivar & $\begin{array}{c}\text { Internode } \\
\text { length }\end{array}$ & $\begin{array}{c}\text { No. of } \\
\text { shoots }\end{array}$ \\
\hline AC Harrow Gold & $3.0 \pm 0.1$ & 19 \\
Bartlett & $3.3 \pm 0.1$ & 13 \\
Harrow Delight & $3.1 \pm 0.2$ & 13 \\
Harrow Sweet & $3.1 \pm 0.1$ & 15 \\
Harvest Queen & $3.7 \pm 0.2$ & 17 \\
Bosc & $4.4 \pm 0.1$ & 14 \\
\hline
\end{tabular}

${ }^{\mathrm{z}}$ Shoots harvested in Feb. 1996, from mature trees ( $>10$ years old) grown on Bartlett seedling rootstock at Harrow, Ont., Canada.

Leaves. The leaves are elliptic. The shape of the base of the leaf blade is right-angled. The shape of the upper part of the leaf blade is right-angled with a pointed acuminate tip. There is little curvature of the midrib. Leaf serrations are small and shallow but distinct. The angle between the petiole and the shoot is between $30^{\circ}$ and $60^{\circ}$, the petiole is medium to long, and stipules are present. The attitude of the leaf in relation to the shoot is horizontal to slightly downward. Actively growing shoot tips are green with little pubescence.

Fire blight resistance. As with other introductions from the Harrow pear breeding program (Hunter et al., 2002; Hunter et al., 1992; Quamme and Spearman, 1983), 'AC Harrow Gold' has excellent resistance to fire blight, similar to or greater than that of 'Kieffer' which is used as the standard for selection (Hunter, 1993). Using natural fire blight infection scores (van der Zwet et al., 1970), 'AC Harrow Gold' had a resistance rating similar to its parents, 'Harrow Delight' and 'Harvest Queen', and much greater than 'Bartlett' (Table 2 ). When actively growing shoot tips were inoculated with a mixture of six virulent strains of E. amylovora, the length of the lesion that developed extended to $\approx 25 \%$ of current season's growth, similar to 'Harrow Delight', 'Harvest Queen', and 'Kieffer', but much less than lesion development in 'Bartlett' (Table 2).

Bloom and pollination. At Harrow, the time of full bloom of 'AC Harrow Gold' is similar to that of 'Harrow Delight' and 'Harvest Queen', and is $\approx 2$ d earlier than 'Bartlett'. First

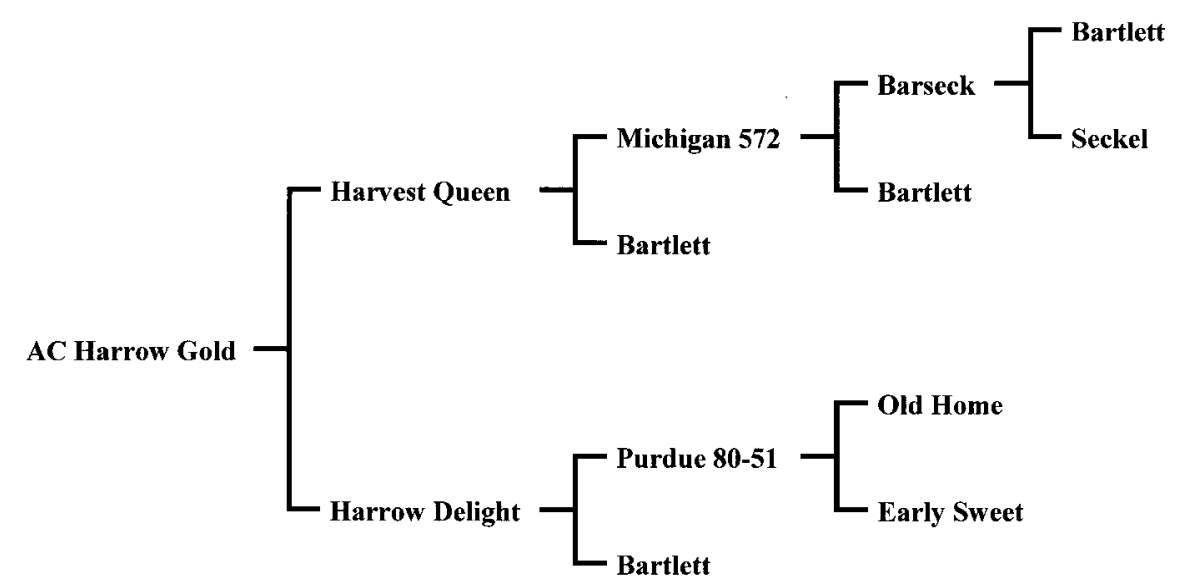

Fig. 1. Pedigree of 'AC Harrow Gold' pear. 
bloom, however, is $1 \mathrm{~d}$ later than 'Bartlett'. Flower clusters typically contain six or seven flowers, occasionally five or eight. Petals are white, almost as long as broad, and touch or slightly overlap. The pink to red anthers are medium in size, and are about level with the stigma.

In controlled pollination tests, fruit set was used to determine pollen compatibility when pollen from a known source was applied to stigmatic surfaces immediately after emasculation of the flower. Because emasculated pear flowers are even less attractive to bees and other pollinating insects than nonemasculated flowers, bagging was not considered necessary. 'AC Harrow Gold' appears to be reciprocally pollen compatible with 'Bartlett', 'Seckel', 'Old Home', and 'Harvest Queen'. While 'AC Harrow Gold' will pollinate 'Harrow Delight', 'Harrow Delight' will not pollinate 'AC Harrow Gold'. Results of reciprocal pollinations between 'AC Harrow Gold' and 'Bosc' have been variable and inconclusive.

\section{Fruit characteristics}

Size, shape and color. Fruits are medium sized, with a fruit length similar to 'Harrow Delight', longer than 'Harvest Queen, and slightly, but not significantly, smaller than 'Bartlett' (Table 3). Fruit diameter of 'AC Harrow Gold' was similar to 'Harvest Queen' and 'Harrow Delight' and significantly smaller than 'Bartlett'. Fruit size and weight are improved by fruit thinning. Fruit shape is symmetrical, pyriform, and slightly concave to straight in profile. Using International Board for Plant Genetic Resources descriptors (Thibault et al., 1983), the predominant fruit shape has been described as $5.2(\approx 25 \%$ of individual fruits) or $5.4(\approx 25 \%)$, while other individual fruits have been described as 3.3 $(\approx 10 \%), 3.4(\approx 15 \%), 7.2(\approx 10 \%)$, and 7.4 $(\approx 10 \%)$. The calyx is persistent at harvest, with medium to long sepals that are convergent to upright. The calyx basin is medium depth and narrow to medium in width, with a slightly ribbed margin. Following ripening at $\approx 20{ }^{\circ} \mathrm{C}$, the skin has an attractive golden yellow ground color (RHS $11 \mathrm{~A}$ or $11 \mathrm{~B}$ ) with no more than a trace of blush on the sunexposed fruit surface, and there is little or no russetting. The flesh is cream to cream-white in color, is exceptionally juicy, and has excellent flavor with a good balance between sweetness and acidity.

Maturity. At Harrow, Ont., Canada, the fruits of 'AC Harrow Gold' mature about 15 Aug., between 'Harrow Delight' and 'Harvest Queen', and $\approx 13 \mathrm{~d}$ before 'Bartlett'. Unlike 'Harrow Delight', pre-harvest fruit drop is not a problem.

Quality. At Harrow, fruits were harvested each year at the normal fresh market maturity for commercial harvest (5-7 $\mathrm{kg}$ pressure). Following ripening at $\approx 20{ }^{\circ} \mathrm{C}$ until 'eating ripe', a sample of 5 to 10 fruits, selected at random, was evaluated for appearance, flavor, texture, number and size of grit (stone cells) in the flesh, juiciness, and core size relative to fruit size. Evaluations were made
Table 2. Ratings of natural and induced fire blight infections of 'AC Harrow Gold' in comparison to 'Harrow Delight', 'Harvest Queen', 'Bartlett', and 'Kieffer'.

\begin{tabular}{lccccc}
\hline \hline & AC Harrow Gold & Harrow Delight & Harvest Queen & Bartlett & Kieffer \\
\hline Rating & $9.6 \pm 0.1$ & Natural infections $^{z}$ & & & \\
Years evaluated & 10 & $9.5 \pm 0.1$ & $9.1 \pm 0.1$ & $4.2 \pm 0.4$ & $9.3 \pm 0.1$ \\
& & 19 & 20 & 18 & 15 \\
Lesion (\% shoot length) & $24.6 \pm 4.4$ & Induced infections & & & \\
Years evaluated & 10 & $16.2 \pm 3.0$ & $22.0 \pm 3.3$ & $62.8 \pm 4.2$ & $23.1 \pm 1.6$ \\
\hline
\end{tabular}

${ }^{2}$ Natural fire blight infections, rated on a scale of 1 (tree dead) to 10 (no blight), are means \pm SE of 10 to 20 years at Harrow, Ont., Canada. The rating system was modified from van der Zwet et al. (1970) by assigning values of $10=$ no visible blight and $9=<3 \%$ infection. For 'AC Harrow Gold', 'Harrow Delight', and 'Harvest Queen', ratings were made on the own-rooted seedling tree. For 'Bartlett' and 'Kieffer', ratings were made on trees grown on Bartlett seedling rootstock in a nearby (within $200 \mathrm{~m}$ ) cultivar evaluation orchard. In both the seedling orchard and the cultivar evaluation orchard, susceptible trees had severe fire blight infections each year.

${ }^{y}$ Induced infections were measured in late July, $\approx 5$ weeks after inoculating $10-20$ actively growing shoots with $20 \mu \mathrm{L}$ of a cocktail of six virulent strains of Erwinia amylovora $\left(10^{8} \mathrm{cfu} / \mathrm{mL}\right)$. Values indicate lesion length expressed as a percentage of total shoot length. Data are means \pm SE of 10 to 22 years. on fruits ripened immediately after harvest. At Harrow, trained panelists rated the appearance of ripened fruits of 'AC Harrow Gold' equivalent to 'Bartlett', 'Harrow Delight' and 'Harvest Queen' (Table 3). The flesh texture was excellent, with little or no grit. The fresh fruit quality rating for 'AC Harrow Gold', as indicated by the weighted score, was similar to 'Bartlett', 'Harrow Delight' and 'Harvest Queen' (Table 3). There were no significant differences between fruits ripened immediately after harvest and fruits ripened after 4 weeks in a common cold storage at $\approx 2{ }^{\circ} \mathrm{C}($ data not presented).

Processing evaluations. When ripened fruits are processed as halves or as puree, 'AC Harrow Gold' is rated similar to 'Harrow Delight' and 'Harvest Queen', but lower than 'Bartlett' (Table 4). While the processed product from small scale trials has been rated good, the quality may not be sufficiently high for 'AC Harrow Gold' to have commercial acceptability for processing in the current market. The commercial processing potential of this new cultivar will be further evaluated when the large scale plantings established in 1999 come into production.

\section{Availability}

'AC Harrow Gold' was tested at the Canadian Centre for Plant Health, Saanichton, B.C., using woody-host and herbaceous-host biological indicators, and by serological and molecular methods, and found to be free of all known viruses, virus-like agents, viroids and phytoplasmas. Virus-tested trees have been planted in the Canadian Clonal Gene Bank at Harrow. 'AC Harrow Gold' is protected under Canadian Plant Breeders Rights legislation,
Table 3. Harvest dates at Harrow, Ont., Canada, and fresh fruit evaluations for 'Harrow Delight', 'AC Harrow Gold', 'Harvest Queen', and 'Bartlett'

\begin{tabular}{|c|c|c|c|c|}
\hline & Harrow Delight & AC Harrow Gold & Harvest Queen & Bartlett \\
\hline Years evaluated & 22 & 12 & 21 & 20 \\
\hline \multicolumn{5}{|c|}{ Harvest dates } \\
\hline Avgerage & 11 Aug. & 15 Aug. & 18 Aug. & 28 Aug. \\
\hline Earliest & 27 July & 31 July & 6 Aug. & 18 Aug. \\
\hline Latest & 18 Aug. & 22 Aug. & 24 Aug. & 9 Sept. \\
\hline \multicolumn{5}{|c|}{ Size $(\mathrm{mm})$} \\
\hline Length & $80.4 \mathrm{a}^{\mathrm{z}}$ & $80.5 \mathrm{a}$ & $72.4 \mathrm{~b}$ & $81.4 \mathrm{a}$ \\
\hline Diameter & $58.7 \mathrm{~b}$ & $59.1 \mathrm{~b}$ & $58.0 \mathrm{~b}$ & $63.4 \mathrm{a}$ \\
\hline \multicolumn{5}{|c|}{ Ratings $s^{y}$} \\
\hline Appearance ${ }^{x}$ & $7.8 \mathrm{a}$ & $7.6 \mathrm{a}$ & $7.5 \mathrm{a}$ & $7.7 \mathrm{a}$ \\
\hline Flavor $^{x}$ & $8.2 \mathrm{a}$ & $8.0 \mathrm{a}$ & $8.3 \mathrm{a}$ & $8.0 \mathrm{a}$ \\
\hline Texture $^{\mathrm{x}}$ & $8.0 \mathrm{ab}$ & $8.5 \mathrm{a}$ & $8.5 \mathrm{a}$ & $7.9 \mathrm{~b}$ \\
\hline Weighted score ${ }^{w}$ & $82.5 \mathrm{a}$ & $83.6 \mathrm{a}$ & $82.9 \mathrm{a}$ & $81.3 \mathrm{a}$ \\
\hline Grit $^{v}$ & $4.1 \mathrm{bc}$ & $4.4 \mathrm{ab}$ & $4.6 \mathrm{a}$ & $3.9 \mathrm{c}$ \\
\hline Juice $^{\mathrm{u}}$ & $4.4 \mathrm{a}$ & $4.1 \mathrm{ab}$ & $4.2 \mathrm{ab}$ & $3.9 \mathrm{~b}$ \\
\hline Core $^{t}$ & $3.0 \mathrm{a}$ & $2.7 \mathrm{~b}$ & $2.4 \mathrm{~b}$ & $3.2 \mathrm{a}$ \\
\hline
\end{tabular}

${ }^{2}$ Means separation within rows by Duncan's new multiple range test, $P=0.05$. Means within rows followed by the same letter are not significantly different.

'Ratings reported are based on evaluations of fruits ripened immediately after harvest.

${ }^{x}$ Appearance, flavor and texture ratings [on a scale of 1 (least desirable) to 9 (most desirable)] were determined each year by two to four trained panelists.

${ }^{w}$ Weighted score $=(3 \times$ appearance $)+(5 \times$ flavor $)+(2 \times$ texture $)$.

${ }^{v}$ Grit rating is on a scale of 1 (undesirable, i.e. large and/or many grit cells) to 5 (desirable, i.e., very small and/or few or no grit cells).

"Juiciness rating is on a scale of 1 (dry) to 5 (very juicy).

'Core size rating is on a scale of 1 (small) to 5 (large). 
Table 4. Ratings of pear halves ${ }^{\mathrm{z}}$ and pear purée ${ }^{\mathrm{y}}$ processed from ripened fruits of 'AC Harrow Gold' in comparison with 'Harrow Delight', 'Harvest Queen', and 'Bartlett'.

\begin{tabular}{|c|c|c|c|c|}
\hline & AC Harrow Gold & Harrow Delight & Harvest Queen & Bartlett \\
\hline Halves & $3.5 b^{x}$ & $3.4 \mathrm{~b}$ & $3.5 \mathrm{~b}$ & $3.9 \mathrm{a}$ \\
\hline Purée & $3.3 \mathrm{~b}$ & $3.2 \mathrm{~b}$ & $3.5 \mathrm{~b}$ & $4.0 \mathrm{a}$ \\
\hline $\begin{array}{l}{ }^{2} \text { Determ } \\
\text { were pr } \\
\text { is the a } \\
\text { desirab } \\
\text { were co } \\
{ }^{\mathrm{y}} \text { Detern } \\
\text { were pr } \\
\text { ratings } \\
\text { desirab } \\
\text { a know } \\
{ }^{2} \text { Means }\end{array}$ & $\begin{array}{l}\text { with masked iden } \\
\text { ed in syrup contai } \\
\text { ge of ratings for } \\
5 \text { (most desirable) } \\
\text { ed to a known 'B } \\
\text { with masked iden } \\
\text { ed with no additic } \\
\text { iscosity, color, ar } \\
\text { amples, including } \\
\text { rtlett' sample. Da } \\
\text { ation within rows }\end{array}$ & $\begin{array}{l}15 \%(\mathrm{~W} / \mathrm{v}) \text { sugar } \\
\mathrm{r} \text {, texture and a } \\
\text { ples, including a } \\
\text { '' sample. Data } \\
\text { aste panels invol } \\
\text { ugar. Processing } \\
\text { avor on a scale } \\
\text { sked identity 'B } \\
\text { esented are mean } \\
\text { luncan's new mu }\end{array}$ & $\begin{array}{l}\text { rance on a sca } \\
\text { ked identity 'Ba } \\
\text { nted are mean } \\
\text { four trained pa } \\
\text { ng for purée is t } \\
\text { (least desirabl } \\
\text { tt' sample, wer } \\
5 \text { years. } \\
\text { e range test, } P\end{array}$ & $\begin{array}{l}\text { ts. Fruits } \\
\text { ar halves } \\
1 \text { (least } \\
\text { sample, } \\
\text { years. } \\
\text { ts. Fruits } \\
\text { verage of } \\
5 \text { (most } \\
\text { npared to } \\
\text { 5. Means }\end{array}$ \\
\hline
\end{tabular}

and is being protected in the European Union. Commercialization rights have been granted to Inter-Plant Patent Marketing, R.R. 2, Niagara-on-the-Lake ON, Canada LOS 1J0 (for North America) and to Star Fruits, Route
d'Orange, 84860 Caderousse, France (for the European Union). Information on tree availability and inquiries regarding the licensing of commercial propagation may be addressed to these agents.

\section{Literature Cited}

Hunter, D.M. 1993. Pear breeding for the $21^{\text {st }}$ century-Program and progress at Harrow. Acta Hort. 338:377-383.

Hunter, D.M., F. Kappel, H.A. Quamme and W.G. Bonn. 2002. 'AC Harrow Crisp' pear. HortScience 37:227-229.

Hunter, D.M., P. Pinsonneault, F. Kappel, H.A. Quamme, W.G. Bonn and R.E.C. Layne. 1992. 'Harrow Sweet' pear. HortScience 27:13311334.

Quamme, H.A. and G.A. Spearman. 1983. 'Harvest Queen' and 'Harrow Delight' pear. HortScience $18: 770-772$

Royal Horticultural Society. 1966. Royal Horticultural Society Colour Chart. Royal Hort. Soc. London.

Thibault, B., R. Watkins, and R.A. Smith (eds.). 1983. Descriptor list for pears (Pyrus). Intl. Board Plant Genet. Resources. IBPGR Secretariat, Rome.

van derZwet, T., W.A. Oitto, and H.J. Brooks. 1970. Scoring system for rating the severity of fire blight in pear. Plant Dis. Rpt. 54:835839. 